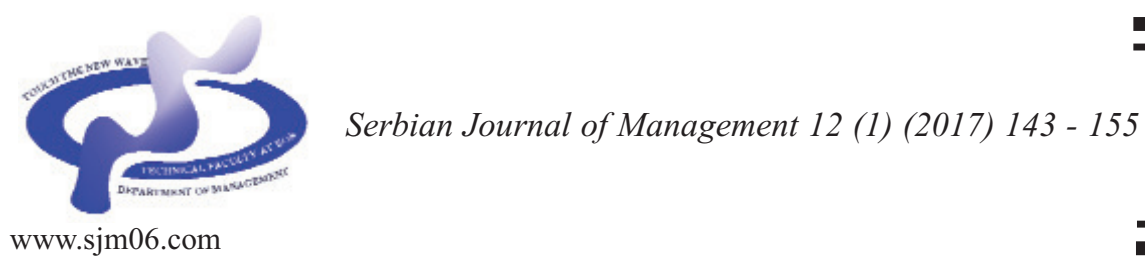

\title{
REDUCING IT COSTS AND ENSURING SAFE OPERATION WITH APPLICATION OF THE PORTFOLIO MANAGEMENT
}

\author{
Alice Lívia Mozsár Kovácsné \\ Óbuda University, Faculty of Economics Károly Keleti, \\ Tavaszmezo str. 17, Budapest, Hungary
}

(Received 23 July 2016; accepted 2 February 2017)

\begin{abstract}
Large companies need to give focus on their cost components related to their information technology. Business growths is supported by their IT and hundreds or thousands of applications worldwide. Top level management needs to focus more on their information strategy and the applications they need to manage. A structured and transparent application landscape supports not only the current business but it also enables faster business growth for the future as well. Structuring and organizing the applications related to the various risks supports secure business and information operations within a company. Capturing the applications gives the companies an overview of their information costs and provides the possibility of measurement and control of their IT costs elements. Application portfolio management and information security management are important elements of the corporate strategies.
\end{abstract}

Keywords: application portfolio management (APM), application portfolio risk, risk, information management, information security management, Information Technology Infrastructure Library (ITIL v3)

\section{INTRODUCTION}

The CIO (Chief Information Office) organization needs to provide daily support to the business through information technology processes. The business areas are under significant pressure to be competitive on the market. Being able to respond rapidly to change is a key factor for market success. Following the changes in the business and its requirements with information technology upgrades and development needs to be managed quickly and efficiently.

This article will show using various case studies and one interview with a multinational company to prove the

\footnotetext{
* Corresponding author: mozsar.livia@kgk.uni-obuda.hu
}

DOI: $10.5937 /$ sjm12-11452 
importance of application portfolio management, cost benefit analysing and risk factors related to applications for large companies. Application portfolio management is an area of the IT responsibilities. APM has dynamic and constantly changing management area that requires continued cooperation between business, IT projects, program managers, business architects, IT architects, and business stakeholders. Less effective, underutilized applications cannot bring real value to the business. More than 100 CIO's globally were surveyed in 2011 and $85 \%$ of the organizations stated that they need to rationalize their application portfolios (Capgemini, 2011). Chief Information Office (CIO) is one organizational area within companies with many different roles and responsibilities and they support the business areas with information technology processes and with IT systems.

The companies are under considerable pressure to be competitive with the IT technologies following regulatory compliance and to reduce the IT costs and focus on the business strategies, requirements and needs. This article focuses on the cost savings opportunities that can be achieved through application portfolio management work for large organizations.

The article's approach is to highlight some gaps in ITIL framework related to application portfolio management and risk management. The different kinds of risks related to applications should be part of the application portfolio management process. Understanding and analysing the different kinds of risk information and data is essential. ITIL is a considered to be a framework of best practice for IT Service Management but it is weak in risk management framework (Sarah, 2012). It would be necessary to expand ITIL with application portfolio management as part of the IT Service Management and to give practices how to focus on application risks as the key challenge is the data security, data quality and complex IT landscape at the same time. Impenetrable, complex, nonstructured and unrecorded applications cause a risk to the organization. "CIOs must recognize that old IT structures may no longer work, says Mike Heim, CIO, Whirlpool." (CIO, 2016).

\section{WHY IS APPLICATION PORTFOLIO MANAGEMENT NECESSARY?}

\subsection{Theoretical Background}

Application portfolio management (APM): Application portfolio management is one part of the organizational architecture it gives a link between the IT and business areas as one element of the information technology management within the large organizations.

Using the ITIL glossary and abbrevations the application and application portfolio is defined but application portfolio management is not.

Application: „Application may be part of more than one IT service. An application runs on one or more servers or clients."

Application portfolio: „A database or structured document used to manage applications throughout their lifecycle. The application portfolio contains key attributes of all applications. The application portfolio is sometimes implemented as part of the service portfolio, or as part of the configuration management system." (ITIL, 2011).

Applications are classified into four 
categories:

1. Strategic information systems: without these applications the business cannot continue daily work, and achieve the business goals.

2. High potential: those application supports the business areas for example research and development.

3. Key operations: "applications on which the organization currently depends for success: improve performance of existing activities, integrate systems to avoid duplication and inconsistencies, avoid disadvantages"

4. Support: applications that are not critical for the business but it still valuable (Ward \& Peppard, 2002).

For the proper categorization of the applications it is necessary to involve the related business areas and the key stakeholders. During the categorization and analysis of the application landscape, consistent information must be collected about legacy applications. Legacy applications are critical to day to day operation but they are based on outdated technologies (Gartner, 2016a).

In recent years more and more survey results demonstrated why it is important to have application portfolio management. After analysing their application portfolio, companies can reduce their legacy applications and the related IT costs and can focusing on improving the rest. As all IT processes, applications, systems with their infrastructure support the business processes and areas it is a key factor to have a deep understanding about all these components and the relationship between them. The effort to understand the applications will help the organizations allocate their IT budgets and resources from non-valuable applications to the assets which support the business for future growth.

One of the key elements in application portfolio management is application rationalization. Part of the rationalization is reducing the number of redundant applications and building a cost benefit analysis. Creating an inventory and structuring the applications will support the business that they will understand which applications support their daily business and as such which are critical for them. Eliminating functional redundancy between applications by merging them or retiring non value applications and improving risk and compliance control are all key results of application portfolio management. A Capgemini research in 2014 involving 1100 CIO's revealed that $70 \%$ of the respondents think that at least $20 \%$ of their applications have redundant functionality which they should eliminate by consolidating the applications (Capgemini, 2014).

\subsection{Issue with legacy applications}

Legacy applications are old applications and most of them are business critical for the business (Gartner, 2016a). Why do companies still manage their hundreds or thousands of their legacy applications? Here are some examples from the past how the companies were impacted by their legacy systems:

1. MF Global Collapse in 2011

"MF Global's collapse was abetted by, among other things, management's failure to integrate or upgrade its various technology systems and platforms for monitoring Treasury Department operations, liquidity risk, and financial regulatory functions.". "It was this failure to forecast company liquidity 
that in the end did it for MF Global”.

2. JP Morgan and the London Whale

The company faced failure because the Value at Risk was calculated with an Excel spreadsheet and because of errors in the manual processes. JPMorgan had $\$ 6.2$ billion loss in 2012 attributed to this legacy process.

\section{RBS IT outage}

In June 2012 thousands of RBS (the Royal Bank of Scotland) bank's customers were affected by a technical glitch in the UK when nearly 60,000 online transactions failed.

"Asked about the problems at RBS, Anthony Browne, British Banker's association said: "The banks are all very aware of this as an issue. A lot of them have creaking IT systems. They are spending $£ 3$ bn a year upgrading their IT systems. It's one of the biggest IT upgrades Britain has ever seen." (Hatstand, 2015).

All the above examples reflect the need to understand, asses and define the information processes, applications and all risk factors within organizations. If these companies had structured inventories and had the legacy applications defined with their respective risk factors they could have avoided those incidents. An important step in the application portfolio management work to assess the legacy applications and the risk factors. Legacy applications are the most expensive ones for companies. Operating legacy applications over 10 years old is a risk for organizations as they may not be able to find the right workforce to support or upgrade the applications and this may increase the number of failed audits (Informatika, 2013).

\section{THE LINK BETWEEN IT SERVICE MANAGEMENT AND APPLICATION PORTFOLIO MANAGEMENT}

The most widely used framework for IT service management is ITIL. Service catalogue management is one recommendation in the framework for companies to capture and monitor their services and the service portfolio management help to decide what services the clients need. ITIL framework describes application management as controlling and monitoring of the applications in their lifecycle. Application management is one part of IT Service Management and it is supported by different processes such as: Problem Management, Incident Management and Change Management (ITIL, 2009). ITIL methodology does not go into the details of application portfolio management steps and what the key attributes of the applications are that need to be recorded in an application portfolio. Developing a service portfolio is an element of the ITIL methodology, creating a business and technical service catalogue (ITIL, 2016). CMDB (Configuration Management Database) is a repository of information of all IT components (Michelberger et al., 2016). CMDB focuses on the data such as: service disk, service request management, applications, business services and people who are part of the system. CMDB also focuses on configuration item types and provides good relationship mapping between different services and impacts caused by changes to one of the services. The CMDB information catalogue can be improved by integrating the application portfolio management data elements into CMDB. The application is already one component of the CMDB so integrating the data set for all 
applications into CMDB is one realized they have applications between the recommendation. $\quad$ ages of 5 and 30 years old. "There are dozens of increasingly difficult to maintain legacy applications. This comes in combination

4. APPLICATION PORTFOLIO MANAGEMENT AND COST BENEFIT ANALYSING

\subsection{The link between information technology costs and the application portfolio}

The companies should identify the Total Cost of Ownership (TCO) improvements for their existing application portfolio (Gartner, 2016b). Management starts to realize the importance of Application portfolio management just they need more time to carry forward their goals to understand more about their information application costs.

According to Gartner company's research, 34\% of the information budgets are the development and maintenance costs and this amount can be decreased by $50 \%$ through optimizing the applications, eliminating legacy applications (Gartner, 2014).

Troux company stated based on their survey of 200 enterprise architects: nearly $60 \%$ of responded that they already have APM or they plan to start it in the next one year and $27 \%$ answered they plan to establish in the next two years. "More than three-fourths $(76 \%)$ of respondents said APM impacts 'all the facets of our business and is highly visible to top level management. They expect it to deliver results, with nearly $55 \%$ saying they can eliminate or retire at least $20 \%$ of their current applications." (Troux, 2011).

A transportation company with several hundreds of million euros IT budget already started to analyse their applications and they with outdated user-interfaces in those legacy systems, lack of documentation and a redundancy of data and functionality." There is a lack of expertise due to an aging workforce, which will lead to severe risks in the future. The costs will rise and the development time will increase when they do not have the expertise to support specific systems. A number of applications are outof-sync with business requirements." (Van Ramshorst, 2013).

These studies and interviews with large organizations highlight how important it is to build an application inventory to reduce the complexity of IT and to have a good overview along with detailed costs information.

\subsection{Case studies for application} portfolio management and reducing IT costs

To demonstrate the importance of and to highlights some key factors of application portfolio management, the case studies below show us how companies become more successful with using the portfolio rationalization methods to create an inventory and management system for their applications.

A) Tata Consultancy Services Company stated that they performed application portfolio management for a leading telecom company, and that with their consultant work the company was able to achieve "substantial savings with ROI of over $26 \%$ in business critical domains." Tata first gathered all information using tools, interviews, workshops with experts and application 
owners. In the next step they analysed the data and focused on some areas such as: Total Cost of Ownership, database versions and consolidating the redundant applications. With their recommendations they could improve the overall health of applications (Tata, 2013a).

B) Infosys supported a financial services provider to rationalize their 300 applications worldwide, used in 20 different countries in four phases. The solution, Infosys provided helped the company to save US\$26M per year and supported decision making with an integrated TCO (Total Cost of Ownership) information related to their applications. They could then give recommendations on which applications to be retained and which to be decommissioned. With the overall TCO (Total Cost of Ownership), information financial management was assisted by making the financial data become clearer (Infosys, 2016).

C) Tata Consultancy Services Company supported on of the largest energy and utilities companies in the USA to identify opportunities to reduce, migrate and retire their applications while giving recommendations for cloud solutions. The company had no centralized business model and IT solutions as they had grown fast in the las five years (Tata, 2013b).

D) One of the world's largest tobacco brands with a 100 year history had 5000 different applications in 180 different locations around the world and they never attempted to centralize and understand their applications. After centralizing their applications they saved millions of dollars and consolidated 63 different ERP systems into one global SAP instance (Tata, 2013a).

E) Before consolidation and simplification, a Fortune 500 BFS managed 2300 applications and they had no information on which business units and domains owned 1000 applications (Tata, 2011).

F) Another success story and case study reported by the Tata Consultancy Services Company is from a client with 60.000 employees worldwide and about $\$ 14.8$ Billion revenue in 2010. Before the application portfolio management program, they managed 2000 applications, facing many problems among them the fact that there was a lot of redundancy in the application portfolio. After application portfolio management implementation they could reduce the third party dependency, thus reducing costs (Tata, 2012).

All those case studies present how companies can justify their IT spending and determine the benefit of the application portfolio management. As the overall and IT budget becomes more constricted, the focus on individual IT costs components grow.

\section{APPLICATION PORTFOLIO RISK, SECURE OPERATION WITH APPLICATION PORTFOLIO MANAGEMENT}

A clear, consistent information security plan is a mandatory element of the information security strategy (Lazányi, 2015). The security plan has many elements for the organizations. For example, how to implement and improve different technologies and how to implement standards practices. Testing and transfer of different information security functions, compliance and risk management are major parts of the security plans.

Long term goals for top management should be to find the common elements 
between risk and application portfolio management and to understand the different application portfolios. The identified risk levels for each application portfolio can support the companies toward safer operation.

This article focuses on the risk factors related to applications. Based on the case studies, company researches is important to note that APM is one of the most important elements of the IT management of the whole organization. The next step is to implement a risk ranking framework into application portfolio management and this framework will be defined as application portfolio risk. The security decisions are made by different factors.

It is recommended to identify different types of risks and to focus information security management within an organization for the high risk applications. The first step in APM can be to set up the major attributes for applications. Identifying and measuring the different risk types should be a part of the application inventory. Operation security is affected by applications. The organizations need to have a clear and transparent captured inventory of their current and retired applications and to focus on the legacy applications. Redundant and legacy applications increase the security breaches.

One approach to asses and monitor the various types of risk factors is using a scorecard in the risk profile for each application. Risk factors for example are: Critical data, technical risks, vulnerabilities and compliance requirements.

Software risk literature focuses on the different types of software development project risks: Technological newness, application size, lack of expertise, application complexity, and organizational environment, lack of top management commitment, failure to gain user commitment, misunderstanding requirement, lack of user involvement, failure to manage and user expectation and changing scope (McFarlan,1981; Barki et al., 1993).

The risks associated with applications: Financial risk, security risk, technology risk, people risk, information risk, business process risk, success risk, political risk, financial risk and technical risk (Schmidt et al., 2001).

All these risk factors should be defined and highlighted as part of the application portfolio risk. A well implemented application portfolio management can reduce the risks in the organization. Application portfolio management work can give an overview on the risks and together with a good framework it can support the security management and increase safe operation within an organization.

Tata Consultancy Services Company provides a good approach to seeing the correlation between the different risk categories and the application portfolio landscape, it defines 4 dimensions.

Application portfolio risk: "Assesses the level of risk to business in terms of the probability of failure or degradation of functionality as well as the extent of impact on business operations due to application, vendor or platform obsolescence."

1. Operational risks: Operational risk considers the impact of application failure on the business. Categorizing the applications will help the work of management as they will know which applications are of high impact, strategic and core applications from the business perspective. It is evident to put more focus and effort on those applications in the portfolio that generate millions of dollars for the business. Taking a look at the application portfolio and rationalizing them - 
for example from a functionality redundancy perspective - will decrease the risks these applications can cause.

As the business doesn't understand the IT area and vice versa a well-functioning APM and Security management can reduce risks.

2. Risk of failure: Building a management process to help companies on where and how to control applications can reduce the risk of failures. Categorizing and reviewing the potential failures should be part of the application portfolio analysis to analyse the different types of information technology failures related to the applications.

3. System complexity: It is necessary to transparently collect and understand the compliance risks associated to the applications. All security regulations and requirements need to be followed throughout the application life cycle: applications are in development, enhancement, maintenance or sunset.

4. Application support risk: All risks in this category are those that can happen while deploying a new system or upgrading an existing one and the human risk is part of this factor (Tata, 2013b).

Using a risk ranking framework, risk scorecards or composite metrics can support the organization to understand and categorize their security risks which are associated with their applications. This can be a good baseline during analysing step of the application categorization. Overall IT management can analyse the different application portfolios. Which portfolio has the riskiest applications and part of the information technology strategy to be more secure to build action plans and to focus on those portfolios, applications within organization. Most of the research focuses on the applications which may cause a high risk for the business areas and organizations or different risk frameworks model how to assess the technical, security risk associated applications. The new approach in this research is to integrate the various types of risks into a risk portfolio and make it one element and step in the application portfolio rationalization. The ITIL framework has some gaps in Risk Management specification because it doesn't define how to deal with risks. Further analysis and research is needed to find the common links between ITIL best practices and application portfolio risks. Integrating application portfolio management and application portfolio risk into the ITIL framework is an opportunity for companies to improve secure IT operations.

\section{RESEARCH}

After the theoretical background and the primary research, an qualitative research, based on the interview methodology was organized to demonstrate the importance of the relationship between APM and risk management. One example of qualitative research that will be presented here is the interview made with an application portfolio manager who works for a large, multinational technology company that is one of the world's largest employers. The interviewee has more than 20 years work experience in the IT field and he keeps track of application portfolios by reviewing the roadmaps, strategy goals. The company has more than ten thousand IT applications worldwide, which coincides with the focus of the research of this manuscript, that is, is worldwide companies exclusively. The answers to the interview questions confirm the importance of APM within organizations 
and highlight the missing links between risk management and application portfolio management. Finally, they show that IT cost reduction measurement is possible with APM, but on the other hand, it is very important to focus on the transformation goals and projects which directly affect the IT application portfolios.

Q1.: What are the benefits, importance and added value of the APM within the organization?

Nowadays all companies own IT applications that support the business processes. It is impossible to imagine running any kind of a business without these IT applications and as such, they need continuous control, development, and maintenance. Depending on the company size, these tasks require significant resources and the enterprises quickly realize that they need to rationalize these expenses. The APM is an added value management systems, the purpose of which is to ensure that each portfolio follows the central strategic goals of the enterprise in order to maintain the homogeneity of technology, and to all IT application costs under control.

\section{Q2.: What areas are involved in the APM work?}

The specialists working in APM work closely with three different areas. The different long-term development plans naturally serve the business community and as such he representatives of different business area participate as the client in the APM-s work.

The APM work closely with the different development teams as well. The development teams work on different developments within the application portfolio.

Q3.: The risk management team and APM team work closely within the organization?

A low-level cooperation exists between the APM and compliance. It is very important to ensure the security of the applications and data integrity. This task exists but only appears in the application support team. Risk management is not integrated into the APM's daily work.

Q4.: Does the company has any integrated framework integrating risk management and APM?

Risk management is usually not part of the Application Portfolio Management, although it should be. The usual drivers are cost reduction and business process optimization to improve efficiency. Both are related to risk management, but the connection is not always obvious. APM is about planning and managing change and change (or lack of it) always has risk associated. Change is usually achieved through transformation projects and risk is associated to those projects, thus risk is indirectly related to APM too. The less obvious connection is to the risk associated to lack of change, or not changing an element of the infrastructure that should be changed. For example, updating/replacing applications with defective or weak security infrastructure are usually sink to the bottom of the priority list and rise only after incidents happen causing sometimes significant tangible and intangible cost to the company. 
Q5.: The APM can reduce the IT costs related to the applications?

The cost that can be saved by APM is hard to determine. It largely depends on the current and planned state of the IT infrastructure, the cost reduction and cost avoidance opportunities and the processes used instead of a formal application APM. Most of the companies are using APM processes, although they might use different nomenclature to describe it. CIO's usually well aware of the state of the infrastructure they manage, they have plans and projects to transform them, but they don't call it APM, but execute the processes as part of their daily business.

Q6.: What type of risks are associated related to the APM? Is it possible to identify, measure and reduce it?

The APM risks are usually associated to the transformation projects. I think the more elusive and usually ignored risk associated to APM is the risk of having no APM process or not a formalized APM process (in some shape or form, even if the process is not called APM) What is the risk of having no coherent plan of transforming the IT infrastructure and align it to the company's IT strategy? What is the risk of not identifying and prioritizing properly transformation tasks to be performed? The situation might be very different case by case, but the risk might be significant. Imagine a piece of software that controls the flow of toxic materials in a chemical plant running on obsolete, unreliable hardware. It might work at this moment, but when will it break, and how many people will die as a consequence? So, risks are there, some are associated to transformation projects some are associated to the lack of APM or to improper execution of the APM process. Project-related risks can be managed through standard project risk management processes, APM-related risks can be minimized by establishing and rigorously executing an APM process.

\section{CONCLUSIONS}

Using the variety of company's survey results and the answers for the interview questions, these three results are presented in this article.

The first one is that application portfolio management is one way for the organizations to eliminate unnecessary IT maintaince and development costs related to their applications. It is a directional proportional relationship between application landscape analysis and information technology cost reduction. It is a basic requirements for large companies to understand the TCO. The IT costs related to applications must be transparent.

The second is based on the theoretical background to implement application portfolio management steps and methodology into ITIL methodology as a part of the Service portfolio management.As part of the integration it is possible to tracke which applications are more important for the business area or which are outdated.

The third is to build, implement and integrate an application portfolio risk dimension into the application portfolio management for large organizations. The integrated methodology can support the companies in complying with different laws, standards and can help ensure the safer organizational operation. Assessing, measuring, grouping and monitoring the 
various types of risks related to different applications is a mandatory element of secure IT management.

As a result of the primary research and the interview, the conclusion is that if the APM is integrated into the corporate IT strategy it can ensure the following of the overall corporate strategy and it can also support cost reduction goals. Risk management is very important for the companies but this management part exists only separately. Further research is necessary to work on the detailed integrated risk and APM management framework and to identify the measurements of the IT costs related to applications.

For growing large companies with many thousands of applications worldwide it is necessary to follow different laws and regulations. The challenge is keeping their information assets and application portfolios secure. The IT strategy decisions driven by business strategy, decisions and the business areas need to understand and follow where they invest their money in the IT area. APM needs to understand, control and monitor how they can rationalize their existing legacy applications. It is a key challenge to support the fast business growth with their current application landscape and the appropiate allocation of IT costs to business needs proportionally. The focus on IT costs elements are expanding, so an application portfolio framework or a methodology analysing, controling and monitoring the different types of information technology costs should be a necessary part of the information management practices.

\title{
СМАҢЕЊЕ ИТ ТРОШКОВА И ОБЕЗБЕЪЕЊЕ БЕЗБЕДНИХ ОПЕРАЦИЈА УПОТРЕБОМ ПОРТФОЛИО МЕНАЏМЕНТА
}

\author{
Alice Lívia Mozsár Kovácsné
}

\section{Извод}

Велике компаније имају потребе да се фокусирају на трошковне компоненте које су повезане са њиховом информационом технологијим. Пословни раст је подржан са њиховим ИТ и стотинама хиљада апликација широм света које би могли да користе. Врхунски ниво меаџмнета се треба да додатно фокусира на информационим стратегијама као и на апликацијама којима треба да управља у перспективи. Структурирани и транспарентни приказ апликација не само да подржава тренутно пословање, већ такође омогућује и бржи пословни раст у будућност. Структурирање и организовање апликација које се односе на различите ризике, подржава безбедно пословање и информационе операције у оквиру компаније. Анализа апликација даје компанијама преглед љихових информационих трошкова и омогућује мерење и контролу елемената трошкова на основу ИТ. Самим тиме, портфолио менаџмент апликација које компаније користе и менаџмент информационе безбедности су важни елементи корпоративне стратегије.

Кључне речи: Портфолио менаџмент апликација (АПМ), портфолио ризика апликација, ризик, информациони менаџмент, менаџмент информационе безбедности, "Information Technology Infrastructure Library (ITIL v3)" 


\section{References}

Barki, H., Rivard, S., \& Talbot, J. (1993). Toward an assessment of software development risk. Journal of Management Information Systems, 10 (2), 203-223.

Capgemini (2011). HP Application Landscape Report, 5-6. https://www.capgemini.com/resource-fileaccess/resource/pdf/Application_Landscape _Report_2011_Edition.pdf, (27.04.2016)

Capgemini (2014). Application Landscape Report, 23-24. https://www.at.capgemini.com/resource-filea c c e s s / r e s o u r c e/p d f/ 2014 - 03 04_alr_v8_web_0.pdf, (28.04.2016)

$\mathrm{CIO}$

http:/www.cio.com/article/2380234/ciorole/state-of-the-cio-2014-the-greatschism.html (21.04.2016)

Gartner (2014). Gartner Application, Architecture, Development \& Integration Summit, May 19-20 in London, U.K. and July 21-22 in Sydney, Australia. http://www.gartner.com/newsroom/id/27110 17 (16.04.2016)

Gartner http://www.gartner.com/it-glossary/legacyapplication-or-system/ (17.04.2016)

Gartner (2016b). IT Glossary, Total Cost of Ownership http://www.gartner.com/itglossary/total-cost-of-ownership-tco/ (16.03.2016)

Hatstand (2015). Capital Market $\begin{array}{llllllllllll}\mathrm{S} & \mathrm{p} & \mathrm{e} & \mathrm{c} & \mathrm{i} & \mathrm{a} & 1 & \mathrm{i} & \mathrm{s} & \mathrm{t} & \mathrm{s} & \end{array}$, http://www.hatstand.com/news/riskcompliance-regulation/legacy-systemdisasters, (11.03.2016)

Informatika Corporation (2013). A practical guide to legacy application retirement, White Paper, 3. https://www.informatica.com/content/dam/i $\begin{array}{lllllllllll}n & f & o & r & m & a & t & i & c & a & -\end{array}$ $\mathrm{com} / \mathrm{global} / \mathrm{amer} / \mathrm{us} / \mathrm{collateral} / \mathrm{white}$ paper/practical-guide-legacy-applicationretirement_white-paper_6957.pdf (15.02.2016)

Infosys (2016). Case Studies, Application portfolio rationalization for a financial services provider. https://www.infosys.com/industries/financial -services/case-studies/Pages/applicationportfolio-rationalization.aspx (12.03.2016)

ITIL (2009). v3 Foundation Study Guide, Release Version 4.2.2.5 http://www.inf.unideb.hu/ fazekasg/oktatas/ ITIL_V3_Study_Guide.pdf (08.04.2016)

ITIL (2011). Glossary and

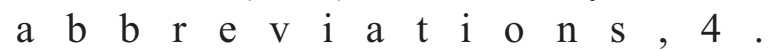
https://www.axelos.com/Corporate/media/Fi les/Glossaries/ITIL_2011_Glossary_GB-v1$0 . p d f(22.02 .2016)$

ITIL (2016). Information Technology Infrastructure Library Guide. http://www.itinfo.am/eng/informationtechnology-infrastructure-library-guide/ (22.02.2016)

Lazányi, K. (2015). Organisational Safety in Health-Care Setting - Literature Review In: Michelberger Pál (Ed.) Management, Enterprise and Benchmarking in the 21st Century Budapest: Óbuda University, 111122.

McFarlan, F.W. (1981). Portfolio Approach to Information Systems, Harvard Business Review, 142-150.

Michelberger, P., \& Dombora, S. (2016). A possible tool for development of information security-SIEM system. Ekonomika, 62 (1), 125-140.

Sarah, V. (2012). Risk Management Model in ITIL https://fenix.tecnico.ulisboa.pt/downloadFile /395144242575/Disserta\%C3\%A7\%C3\%A3 o.pdf (03.03.2016)

Schmidt, R., Lyytinen, K., Keil, M., \& P. 
Cule. (2001). Identifying Software Project Risks: An International Delphi Study. Journal of Management Information Systems, 17 (4), 5-36.

Tata Consulting Services (2011). Next generation application portfolio rationalization, How IT simplification and standardization ensure business growth, White Paper, 18. http://tcs.com/SiteCollectionDocuments/Wh ite $\% 20$ Papers/Consulting_Whitepaper_Next -Generation-Application-PortfolioRationalization_09_2011.pdf (06.04.2016)

Tata Consulting Services (2012). TCS Standardizes application and process management to deliver operational leadership for a global consumer products $\begin{array}{llllll}\mathrm{g} & \mathrm{r} & \mathrm{O} & \mathrm{u} & \mathrm{p}\end{array}$ http://www.tcs.com/SiteCollectionDocumen ts/Case\%20Studies/Consulting_Casestudy_ TCS-Operational-Leadership-GlobalConsumer-Products-Group_0312-1.pdf

Tata Consulting Services (2013a). TCS successfully optimizes the application portfolio of a leading telecom company. http://www.tcs.com/SiteCollectionDocumen ts/Case \%20Studies/Consulting-Casestudyapplication-portfolio-telecom-0513-1.pdf (05.02.2016)

Tata Consulting Services (2013b). Application portfolio rationalization, How IT simplification and standardization ensure business growth, White Paper, 10-13. http://www.tcs.com/SiteCollectionDocumen ts/White\%20Papers/Application-PortfolioRationalization-IT-SimplificationStandardization-10-13-1.pdf (04.04.2016)

Troux (2011). Application portfolio management ranks top in new EA survey. http://www.troux.com/enterprisearchitecture-blogs/application-portfoliomanagement-ranks-top-new-ea-survey (02.02.2016)
Van Ramshorst, E. (2013). Application portfolio management form an enterprise architecture perspective, Master's Thesis, Utrecht University, Faculty of information and Computing Sciences, 50-53.

Ward, J., \& Peppard, J. (2002). Strategic Planning for Information systems, John Willey \& Sons Ltd., 13-14. 